Galileo and the Freedom of Thought. By F. SHERwOOd TAYLOR, Ph.D., M.A., B.Sc. Pp. 212. London: Watts \& Co. 1938. Price, $7 / 6$.

In this book the author has told the story of Galileo and his discoveries, and his place in the history of scientific thought. He has given a good description of dark ages dominated by the superstitions of the church and the Aristotelian philosophy. The struggle between Galileo and the Church is well elucidated, and even if Galileo never said " Eppur si muove," one feels that the slogan accurately reflects his real thoughts. Galileo's observations and experiments are well described and illustrated, and the book is enriched with several portraits and plates.

\title{
OBITUARY
}

\section{JOHN , MARTIN WHEELER}

John Martin Wheeler was born on November 10, 1879. His family originally came to America from Cranefield, Bedfordshire. He received his early education in the public schools of Burlington and the University of Vermont from which he graduated in arts in 1902 and in medicine in 1905. In 1906 he received the B.Sc. degree and during the years 1906 and 1907 he was an instructor in anatomy. In 1908 John Wheeler became an intern in the New York Eye and Ear Infirmary. His natural ability and hard work soon gained him a prominent place among ophthalmologists. He served on the Councils of the American Ophthalmological Society and the American Academy of Ophthalmology and Oto-laryngology, and in 1933 he became President of the latter.

Wheeler was appointed Professor of Ophthalmology at Columbia University in 1928 and three years later he became Director of the newly-built eye institute at the Columbia-Presbyterian Medical Centre.

His special interest lay in surgery, particularly plastic surgery around the eyes, a field in which he felt that ophthalmic surgeons did not do nearly so much as they should.

Three years before his death he lost one eye but so great was his surgical skill that after a brief period of practice he was able to operate as efficiently as before this adversity fell upon him.

In 1928 the University of Vermont conferred upon him an honorary degree of D.Sc., and in 1933 he received a similar award from Middlebury College. In 1931 the decoration of Commander of the Order of the Cross of Siam was conferred upon Wheeler after he had operated on the King of Siam's eyes, and in the same year he was awarded the Leslie Dana Medal for distinguished service in the conservation of sight. 


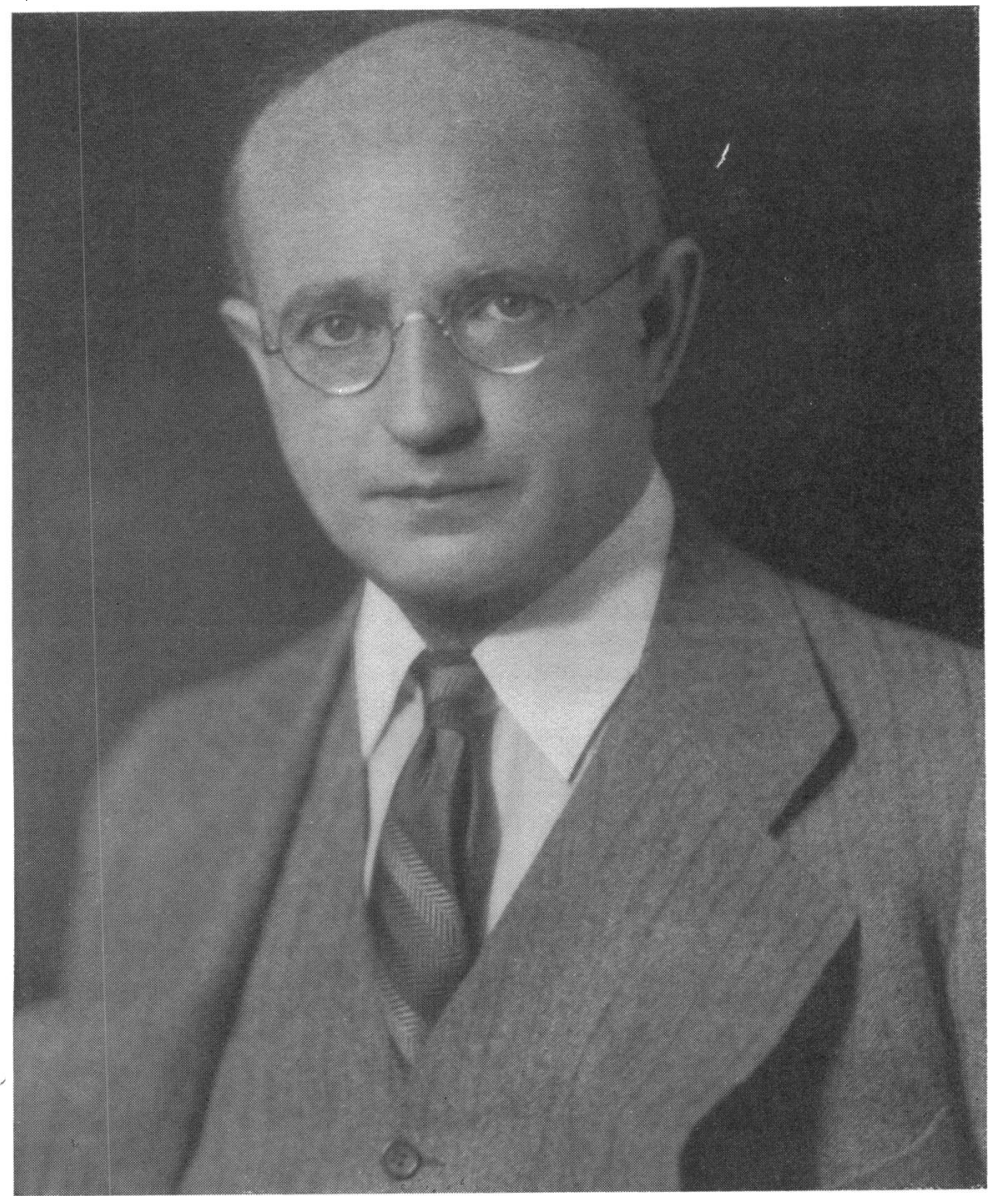

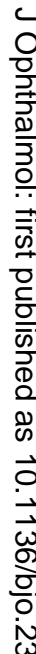

JOHN MARTIN WHEELER

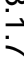

oे

$\stackrel{\circ}{3}$

ำ

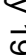

డ్ర

인

ํㅡㅇ

ํำ

읔

룽

흠

훅

응

올

오

을

N

N

W

ত

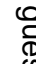

曲

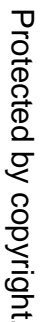


His widow and four children survive him. Wheeler's death is a great loss to ophthalmology.

We are indebted to $\mathrm{Mr}$. Basil Graves for the following appreciation :-

It is difficult for one who knew John Wheeler and his family well to do justice to his memory in the compass of a few words.

Dr. Wheeler, though a disciplinarian, was a craftsman and an artist who had in full measure that spirit which, seeking neither prestige nor shelter in scholastic obscurity and unfettered by the claims of any inflexible synoptic formalism, welcomes every opportunity of enquiry into change; and which, in the desire to record and explain change, creates problems in the very act of seeking them.

Dr. Wheeler's associates and students always speak of his unselfish interest in their progress. It is said that his chief interest lay in the development of young men and in the perfection of their operative technique. He was a man of quiet courage and masterly skill. In the surgery of the eye "he had no peer." $\mathrm{He}$ had a remarkably intuitive respect for the vitality of living tissue and a healthily sceptical attitude towards any disparagement of "the things of sense." He was never resentful of the accomplishments of others and a colleague has stated that he knew none who was ever jealous of his. He would always refrain from publishing anything until he felt sure that it would probably endure. Several instances could be quoted to illustrate how he preferred to demonstrate his original ideas to his friends and visitors at his clinic, permitting them the opportunity of using the ideas and even of publishing the work if they so chose. He was acutely critical of his own work but generously forgot any mishaps or mistakes of his associates. The American Journal of Ophthalmology (October, 1938) writes:- "It was his way to ask opinions of whomever he was with. He was a good listener. Quite free from the habit of interrupting, he would, in fact, often wait a noticeable time after the speaker had finished before replying. His own suggestions were usually made with a twinkle in his eyes-a very characteristic feature which was never far away and which was one of his most lovable attributes, for he was endowed with a delightful sense of humour." This encouragement and tolerance of the suggestions of others, particularly those of juniors, resembled the attitude of the late Mr. Treacher Collins towards constructive thought. Wheeler, who first met Collins when on a visit to England about fifteen years ago, never ceased to express his admiration for the whole of Collins' work and outlook. He published some fifty original communications and, as was the case with the work of Treacher Collins, they were characterised by the absence of dependence upon the bibliographical compilations of the work of others. Disappointment has been 
expressed that Wheeler did not write a text-book on plastic surgery of the eye. It is a matter of no surprise that he did not and the reason is probably amply provided in any historical consideration of the psychology of the craftsman and of the socially, if not biologically, inevitable demarcation between the mode of thought of the craftsman and that of the academician; his approach to problems recalled the initiative of those of the now well-known scientists of the XIX century who achieved what they did largely because they began as independent amateurs in their chosen subjects.

Owing to the social organisation of his unique achievements, as much as to the manner in which he himself pursued his life's work, the passing away of John Wheeler, at the age of fifty-eight when he was in full professional activity, will fortunately not mean that the world will be deprived of work of rare value through the loss of one whose heart-to quote words written in his own country-was the very heart of ophthalmology. He has left, in the institution in New York of which he was the Director, a legacy of tradition and achievement which, owing to his foresight and kindness, will be perpetuated by the surviving group of men who, in helping him, derived so much from the example of his sustained and generous help.

\section{NOTES}

\section{Deaths}

THE death of Professor William McDougall deprives psychology of a forceful and distinguished exponent. He is best known for his epoch-making book on the Instincts contained in his "Introduction to Social Psychology," and for his many works on social and abnormal psychology advocating his hormic theory. But it may be doubted whether these works represented his greatest claims to honour as a scientist. These were probably his highly original experimental studies on colour vision (published-and buried - in "Mind," a journal of limited circulation), on after-images, and above all on recurrent vision (published in the British Journal of Psychology). All this work was done during his tenure of posts at University College, London, and at Oxford, before his migration to the United States, as the successor of Professor Münsterberg at Harvard. Mention should also be made of his studies on cutaneous sensibility in primitive races as a member of the Cambridge Anthropological Expedition to the Torres Straits in 1898. In his experimental and anthropological work he was a worthy disciple of his Cambridge teacher, Dr. W. H. R. Rivers.

Ralph Kanthack, the elder brother of the late Dr. A. A. Kanthack, the distinguished Professor of Pathology, died on November 12, 